\title{
Thermal processing and allergenic potential of egg for children
}

\author{
Chantal Brossard ${ }^{1}$, Marie-Anne Legoux ${ }^{1}$, Julie Chabauty ${ }^{1}$, Fabienne Rancé ${ }^{2}$, Agnès Juchet ${ }^{2}$, Martine Drouet $^{3}$, \\ Evelyne Paty ${ }^{4}$, Sandrine Legoué-Morillon ${ }^{5}$, Françoise Nau ${ }^{6}$, Olivier Tranquet ${ }^{*}$, Chantal Brossard ${ }^{1}$
}

From Food Allergy and Anaphylaxis Meeting 2014

Dublin, Ireland. 9-11 October 2014

Egg belongs to the list of ingredients that must be labeled because of its frequent involvement in food allergies especially in childhood. Several thermal processes are commonly applied to egg and it is known that some egg-allergic people can tolerate well-cooked egg. Food allergens are characterized by their ability to elicit IgE antibodies (sensitization) in susceptible individuals and to display several IgE-binding epitopes. Allergenic potential influenced by different structural levels (sequence, 2D/3D structures as well as supra-molecular organization) can be greatly impacted by all modifications of these structures due to processing. Our work aimed to analyze the impact of pasteurization and boiling of egg and its fractions on in vivo reactivity and its relation to IgE-binding profiles to egg allergens/fractions in a cohort of children allergic to egg.

Allergic children ( $\mathrm{n}=52,18$ months - 7 years old) were recruited, all had positive skin prick-tests (SPT) to raw whole egg and egg white and $80 \%$ to raw egg yolk. Reactivity to pasteurized and boiled fractions was evaluated by SPT. Sera samples taken at inclusion were used to draw profiles of IgE-reactivity against known allergens and proteins of egg white and against fractions of egg yolk by ELISA. Relative STP data and IgE-binding profiles were analyzed by hierarchical classification to evidence typical profiles of reactivity in this cohort.

Pasteurization had very limited impact on structure of egg and only $10 \%$ and $5 \%$ of children STP became negative with pasteurized $\left(66^{\circ} \mathrm{C}, 6 \mathrm{~min}\right)$ whole egg or egg white. Boiling $\left(100^{\circ} \mathrm{C}, 10 \mathrm{~min}\right)$ greatly changed structure of egg products and had a higher effect than pasteurization since $55 \%, 27 \%$ and $67 \%$ of children SPT remained positive to boiled egg and yolk and white fractions. Two typical STP

${ }^{1}$ Institut National de la Recherche Agronomique, UR1268 BIA, Nantes, France Full list of author information is available at the end of the article behaviors were evidenced by classification in this cohort. IgE-binding profiles largely differed among children but three typical profiles where extracted from data. Contingency analysis revealed links between typical STP and IgE-binding profiles with possible explanation of tolerance to cooked egg.

\section{Authors' details}

'Institut National de la Recherche Agronomique, UR1268 BIA, Nantes, France. ${ }^{2} \mathrm{CHU}$ Toulouse - Pediatrie - Pneumologie, Allergologie, Toulouse, France. ${ }^{3} \mathrm{CHU}$ d'Angers - Departement Pneumologie - Unite Allergologie Generale, Angers, France. ${ }^{4} \mathrm{CHU}$ Necker, Pneumo Allergologie Infantile, Paris, France. ${ }^{5} \mathrm{CHU}$ de Nantes - Centre de Recherche et d'Education en Allergie Alimentaire, Nantes, France. ${ }^{6}$ UMR1253 INRA/AgroCampus Ouest, Sciences et Technologie du Lait et de I' oeuf, Rennes, France.

Published: 30 March 2015

\section{doi:10.1186/2045-7022-5-S3-P134}

Cite this article as: Brossard et al.: Thermal processing and allergenic potential of egg for children. Clinical and Translational Allergy 2015 5(Suppl 3):P134.

Submit your next manuscript to BioMed Central and take full advantage of:

- Convenient online submission

- Thorough peer review

- No space constraints or color figure charges

- Immediate publication on acceptance

- Inclusion in PubMed, CAS, Scopus and Google Scholar

- Research which is freely available for redistribution

Submit your manuscript at www.biomedcentral.com/submit
() Biomed Central 